\title{
RUSSIAN EMIGRATION AND BRITISH MARXIS'T SOCIALISM
}

Britain's tradition of political asylum has for centuries brought refugees of many nationalities to her shores. The influence both direct and indirect, which they have exerted on British life has been a factor of no small importance. The role of religious immigration has frequently been examined, that of the socialist emigrés from Central Europe has so far received less detailed attention.

Engels was a frequent contributor to the "Northern Star" at the time of the Chartist upsurge in the mid-Igth century, ${ }^{1}$ Marx also contributed. ${ }^{2}$ George Julian Harney and to a lesser extent other Chartist leaders were measurably influenced by their connection with European political exiles. ${ }^{3}$ At least one of the immigrants is reputed to have been involved in plans for a Chartist revolt. ${ }^{4}$ The influence which foreign exiles exerted at the time of Chartism was to be reproduced, although at a far higher pitch of intensity in the events which preceded and followed the Russian Revolutions of March and October I9I 7 .

The latter years of the igth century saw a marked increase of foreign immigration into Britain. Under the impact of antisemitism over I,500,000 Jewish emigrants left Czarist Russia between I88 I and I9I0, 500,000 of them in the last five years. The number of foreigners in the UK doubled between 1880 and $1901 . .^{5}$ Out of a total of 30,000 Russian, Polish and Roumanian immigrants the Home Office reported that no less than 8,000 had landed between June 1901 and June I902.6

I Mark Hovell, The Chartist Movement, Manchester 1925, p. 286; A. R. Schoyen, The Chartist Challenge, London 1958 , pp. $130-13 \mathrm{x}$.

2 Mark Hovell, The Chartist Movement, p. 286; Northern Star, 9 October, 1847.

${ }^{3}$ Mark Hovell, The Chartist Movement, p. 287; A. R. Schoyen, The Chartist Challenge, pp. I35-1 45; The Red Republican, London (issues of I 850), edited by C. J. Harney.

4 Mark Hovell, The Chartist Movement (The Pole, Major Beniowski), pp. i76 f.; A. R.

Schoyen, The Chartist Challenge, pp. 88, 90, 92.

5 Committee of the Delegates of the Russian Socialist Groups in London, An Appeal to Public Opinion, London 1916, p. I6; Douglas G. Browne, The Rise of Scotland Yard, London r956, p. $279 .^{2}$

6 Douglas G. Browne, The Rise of Scotland Yard, p. 279. 
Not insignificantly it has been recorded that "Amongst the countries where ... Russian 'political offenders' looked for shelter Great Britain took first place."'

The largest colony of immigrants settled in East London and perhaps the next largest in Leeds. Other areas were also represented, amongst them, Newcastle and Glasgow. London's East End and Leeds were each major centres of the clothing trade. The industry, naturally adapted to small scale production, much of it involving low wages and sweated conditions, rapidly absorbed large quantities of immigrant labour. At the same time, despite its seasonal character, the handicraft nature of the industry allowed a minority of highly skilled cutters and others to earn wages which raised them to amongst the best paid of industrial workers. The varied character of the labour force thus provided a small minority with the means and opportunity for leisure and self-education, whilst at the same time, by virtue of the sharp contrasts in conditions, spurring on the more socially conscious amongst them to a radical and forthright attitude to political and social affairs in general. ${ }^{2}$

No doubt, the larger proportion of the immigrant population overwhelmed with the burden of maintaining mere existence played little or no active part in British political life. ${ }^{3}$ On the other hand, amongst some, continual reports of pogroms and repressions at home, combined with the especial economic, racial, social and political pressures to which an immigrant population is customarily subject, to produce an unusually radical and intense attitude to the political life of the land of their adoption. ${ }^{4}$

As early as 1885 , one year after the foundation of the SDF, emigré anarchists in East London were publishing a paper in Yiddish entitled

${ }^{1}$ Committee of Delegates of the Russian Socialist Groups in London, An Appeal to Public Opinion, London 1916, p. 7 .

2 Shirley W. Lerner, Breakaway Unions and The Small Trade Union, London 1961, pp. 85-87. Sam Elsbury, later an important figure in Communist union history, is an excellent example of the militant highly skilled cutter. Ibid., p. roo et seq.

${ }^{3}$ Rudolf Rocker, The London Years, London I956. Introduction by Joseph Leftwich, p. 27-28. - "The Jews whose lives were fallen in pleasant places", as the Jewish Chronicle termed it, did not, with few exceptions, want to put themselves out to "become their brothers keepers". There was a cold attitude amongst responsible Jewish organisations towards "our poor East End brethren". For the apathy of large sections of population, Rocker The London Years, pp. 78-82. For difficulties of organisation, ibid., p. I 22 et seq. 4 Rudolf Rocker, The London Years, pp. 192-193, relates how in November I 909 on the eve of the London Lord Mayor's Show, he had personally to intervene in order to dissuade a small group of anarchists from carrying out a plan to throw a bomb at the procession. 
the "Arbeter Fraint" (Workers Friend) which at first circulated in Britain and later it seems was also smuggled into Russia by secret channels. ${ }^{1}$ This was probably the first specifically anarchist journal to be published in Britain. It is an indication of the immigrant influence on a certain section of British political life that Prince Peter Kropotkin, who arrived in Britain during 1876 may fairly be rated as one of the founders of British anarchism. ${ }^{2}$ By 1903 the size of the immigrant population, the intensity of feeling against Czarist dictatorship were already sufficient to bring 25,000 people to demonstrate in Hyde Park, against the Kishineff Pogrom which took place that April. ${ }^{3}$

Engels had moved to London from Manchester in $1870.4^{4}$ The founders of Russian Marxism, George Plekhanov and Paul Axelrod, considered the visit to his house in Regents Park Road a necessary pilgrimage whenever they were in London ${ }^{5}$. Vera Zasulitch, wholived in London was another regular visitor as indeed was Stepniak, the terrorist author of "Underground Russia"."

To the political exiles, the English scene must have at first appeared mystifying and almost incomprehensible. The English trade unions, although by Russian standards extremely powerful, must yet by the same test have appeared conservative, if not downright reactionary. The unashamedly Christian and nonconformist Independent Labour Party must have seemed an almost inexplicable conundrum. Only the SDF professed the marxist and by implication, atheistic creed to which the continental socialists were in the main attached. Yet the SDF led by a top-hatted stockbroker, H. M. Hyndman, was in itself bound to prove a puzzle, not least to those immigrants to whom, "The Revolution" as demonstrated in 1905, was not a text-book phrase, but an unforgettable part of their own personal experience. Nevertheless, the marxist character of the SDF proved it to be their natural home. Marx and Engels, the party's ideological mentors, were both German. The largest party of the 2nd International was German, the greatest intellectuals of the socialist movement of the same

1 Rudolf Rocker, The London Years, pp. 1 23, 136, 177 .

${ }^{2}$ George Woodcock and Ivan Avakumović, The Anarchist Prince, London 1950, p. I45.

Kropotkin with others founded the Freedom Group in I 886. Ibid., p. 208.

${ }^{3}$ Rudolf Rocker, The London Years, pp. 162-165.

4 Gustar Mayer, Friedrich Engels, London 1936, p. 197.

${ }^{5}$ Edward Bernstein, My Years of Exile, London r921, p. 219. Leonard Schapiro, The Communist Party of the Soviet Union, London 1960, p. 819 (for tole as founder). Leopold H. Haimson, The Russian Marxists and the Origins of Bolshevism, Cambridge (Mass.) I955.

- Edward Bernstein, My Years of Exile, p. 219; (Stepniak) p. 214. 
nationality. Eleanor Marx Aveling, Marx's daughter, had sat on the first executive of the SDF. ${ }^{1}$ Belfort Bax, an intellectual, a philosopher and historian of standing, was to be a prominent figure in the party almost the whole of its life. ${ }^{2}$ In such circumstances, continental immigrants with a marxist background were, one suspects, much more readily accepted inside the SDF than they would have been, within the more peculiarly British ILP.

Yet if it be true that the SDF was the most congenial political home for Eastern European immigrants, this should not hide the fact that the party's attitudes and policies were markedly different from those to which the new arrivals were accustomed. Under conditions of Czarist repression the socialist movement found itself restricted to agitational rather than propagandistic tasks, to preparing for insurrection, rather than lecturing on the inevitability of the socialist millennium. The SDF by contrast was inclined to disdain practical activity, poured scorn on trades unionism ${ }^{3}$ and was inclined to lecture the working classes with a rather rigidly mechanistic version of the materialist conception of history. The party's apparent belief in a version of the "Iron Law of Wages", 4 the professed opinion of some of its most able leaders that income tax was irrelevant to the working class, since being a charge on wages, it was finally paid by the employers, were indications of a disturbing divorce from the realities of working class life. ${ }^{5}$ So little faith indeed did the leaders place in the relevance of their practical "palliative programme" that it remained unchanged, like a form of canon law, from 1884 right into the 2 oth century. ${ }^{6}$

The SDF had plainly failed to move with the times. The injection of an intense, experienced and by implication, highly critical and devoted leaven into its ranks was bound to provoke a conflict. The course of events in the decade before I9I4 was to show that the alien opposition would find itself in the mainstream of a native British current of opposition.

Those immigrants who entered British political life were not in any

${ }^{1}$ H. W. Lee and E. Archbold, Social Democtacy in Britain, London 1935, p. 69.

${ }^{2} \mathrm{H}$. W. Lee and E. Archbold, Social Democracy in Britain, pp. 82-83; E. Belfort Bax, Reminiscences and Reflections, London 1918, p. 73 et seq.

3 "We are opposed to strikes altogether", wrote Hyndman in April 1903. "They never were a powerful weapon and now they are quite out of date." Justice, I 8.4.1903.

4 "... great strikes can force concessions ... they cannot alone effect any permanent improvement in the conditions of those who labour." H. W. Lee, The Great Strike Movement of I9I I, London, p. I6.

${ }^{5}$ John Maclean. Biographical material in possession of Maclean's daughter Nan Milton.

${ }^{6}$ See Hyndman's address to the Founding Conference of the British Socialist Party.

British Socialist Party Annual Report, London igi 2. 
sense cut off from the activities of their compatriots abroad. Political contact between different centres of emigration seems to have been regularly maintained, whilst correspondence with relations at home would have continued as a matter of course. The conditions of political life in immigration also made inevitable a continuing interchange of personnel between the various centres. Thus when Lenin and his wife, Krupskaya arrived in London in April, 1902, they were met by an exiled party member and were soon in the centre of a whole web of immigrant activity. ${ }^{1}$

Trotsky visited London for the first time that year, knocking up Lenin in the middle of the night of his arrival. Lenin and Trotsky together toured London, amongst other places visiting the Brotherhood Church at Islington where later the historic 1907 Party Congress would be held. ${ }^{2}$ At Lenin's suggestion Trotsky was accommodated with Vera Zasulitch, Martov and others who played a vital role in Russian political history. During his stay Trotsky lectured at Whitechapel dealing sharply with Tchaikovsky and also with emigré anarchists such as Tcherkesov, who questioned him. ${ }^{3}$

Whilst Trotsky was in London Plekhanov arrived on a brief visit. It is indicative of the interaction that existed between the parties that on calling Trotsky found Plekhanov engrossed in conversation with J. B. Askew, a prominent SDF critic of Hyndman, and Max Beer, who as correspondent of "Vorwärts" was well known in SDF circles. ${ }^{4}$

Lenin had come to Britain largely because "it was no longer possible to print 'Iskra' at Munich as the owner of the printing press did not want to undertake the risk." 5 In London it was the SDF which by placing the resources of their own Twentieth Century Press at Lenin's disposal enabled the paper to be printed. As Lenin himself was to relate gratefully later "Quelch himself had to 'squeeze up' in his office: a corner separated off by a thin partition had to serve him as an editorial room". ${ }^{6}$ The corner was furnished with a very small

1 N. Krupskaya, Memories of Lenin, Vol. I, London I930, p. Go et seq. (Krupskaya gives an excellent impression of the mobility of emigré political life); L. Trotsky, Lenin, London 1925, p. 27 et seq.; L. Trotsky, My Life, New York I930, p. 142 et seq.; Rudolf Rocker, The London Years, pp. I 28, 177.

${ }^{2}$ N. Krupskaya, Memories of Lenin, p. 85; Max Eastman, Leon Trotsky - Portrait of a Youth, London 1926, p. 174 .

${ }^{3}$ Max Eastman, Leon Trotsky - Portrait of a Youth, pp. i 71-172; L. Trotsky, My Life, p. 145 .

${ }^{4}$ Max Eastman, Leon Trotsky - Portrait of a Youth, pp. I 72-I 74; L. Trotsky, Lenin, p. 39.

5 N. Krupskaya, Memories of Lenin, Vol. I, p. 66.

6 It was Harry Quelch, editor of "Justice", who arranged for Trotsky to be admitted to the

British Museum Library. Trotsky arrived in October. See Trotsky, My Life, p. 205. 
writing table, with a bookshelf over it and a chair. "When [Lenin] visited Quelch in this 'editorial room' there was no room for another chair". ${ }^{1}$ Between its foundation in 1898 and the Russian Revolution of 1917 the Russian Social Democracy held five congresses. The first at Minsk was only a limited success. The others were held in immigration. The 1903 congress started in Brussels and following police intervention moved to London at an early stage of the proceedings. Congresses were held again in 1905, 1906, 1907 and of these two, in 1905 and 1907 were held in London. ${ }^{2}$ Thus three of the four congresses held in immigration took place in London. The most crucial decisions in the history of the Russian Socialist Movement were taken on British soil.

Nor was this all. Anti-Czarist feeling was strong in Britain. Sympathy for the rgos Revolution ran high enough to move the sluggish and conservative minded Labour Representation Committee to come to its aid. In January and February I 905 the LRC sent a total of $£$ i so to Russia, most of it intended for the relief of widows and orphans of men killed in the fighting at St. Petersburg. An appeal to all affiliated societies made at that time was expected to raise this figure to $£$ soo. Alexeyev, a Bolshevik emigré in London was invited to attend a full meeting of the LRC and wrote to Lenin informing him on the position. ${ }^{3}$

Yet, although links had existed before, it was not until after the revolution of 1905 that the Russian influence on British Social Democracy became pronounced. This was partly due to the arrival of a new wave of immigrants following the suppression of the revolutionary movements and probably also to the growing interest in political questions amongst previous arrivals in Britain, an interest stimulated by recent events in Czarist Russia.

Already before igos a surprising number of British socialists had been involved in the affairs of the Russian Revolutionary movement. S. G. Hobson, in his biography, relates how he regularly provided English passports for Social Revolutionary emigrés on the run. In the winter of 1904 Hobson was directly involved in smuggling 6,000 Browning revolvers into Russia, the guns being packed in barrels of lard at a warehouse in East Ham and then shipped into Russia via Riga. When difficulties ensued, Hobson visited Reval to clear them up. On his return he was visited by the Special Branch. ${ }^{4}$

Important sections of the SDF membership also seem to have been

\footnotetext{
1 Lenin on Britain (a compilation), London 1934, pp. I18-1 19.

2 Leonard Schapiro, The Communist Party of the Soviet Union, Appendix II, p. 604.

Lenin on Britain, pp. 107-109.

4. G. Hobson, Pilgrim to the Left, London I938, pp. I25-1 28.
} 
involved in gun running. Arms bought on the continent were shipped to England via Newcastle, there stored and later moved up to Scotland for despatch to Russia via Baltic steamers. This continued undetected for several years until in May 1907 arms were discovered at Newcastle-on-Tyne. A prosecution followed. Later the same summer further charges were brought against members of the SDF in Glasgow and Edinburgh. I 5,000 rounds of ammunition were found in the home of J. F. Reid of Glasgow. Eighty Browning pistols and $1,000,000$ cartridge slips were discovered in two raids in Edinburgh. ${ }^{1}$ The Scots escaped with a fine. Daniel Currie of Newcastle went to a prison for his activities on behalf of the Russian Revolutionary Movement.

Amongst those in charge of munitions smuggling at this time was Maxim Litvinov. Present at the 1903 London party congress, Litvinov was employed between 1906 and I 908 supervising gun running operations in Central Europe. In January 1908 he was expelled from France and with Gorki's aid obtained a position with the London publishers, Williams and Norgate. Adopting the name of Maxim Harrison he settled in Hampstead. In I 9 I 2 he was accredited Bolshevik emissary to the Bureau of the Second International. ${ }^{2}$

If the gun running was important, far more significant were the facilities provided by Britain and the British socialist movement for the congresses of 1903, 1905 and 1907. The congress of 1903 seems to have escaped notice in the socialist press. That of 1905 was held between April 25 and May ro and after two months' delay to allow the delegates to disperse, was duly reported in "Justice".

"Justice" printed the report and the full text of the five main policy resolutions "as we received it", pointing out however that the congress "was held not by the whole of the Social Democratic Labour Party of Russia" but by the Bolshevik section only, and contesting the validity of the Bolshevik claim that this was a congress of the whole party. $^{3}$ It is indicative of the unsectarian attitude of British socialists towards the competing Russian emigré groups of this time that this statement seems to have brought forth no public criticism.

The truth would seem to be that the differences dividing the various groups were not in any sense clearly understood. No doubt it was for this reason, that two years later, at the time of the 1907 Congress "Justice" felt it necessary to publish an article explaining the differences between the two main sections of Russian Social Democracy. The author Theodore Rothstein did not hesitate to take sides in the controversy. "A portion of the Social Democrats, the Lenin section",

1 H. W. Lee and E. Archbold, Social Democracy in Britain, London 1935, pp. 148-1 54.

2 Arthur Upham Pope, Maxim Litvinov, London 1943, Pp. 5I, 68, 84, 96, 103 et seq.

3 Justice, I5.7.1905. 
he wrote, "say the proletariat has to go hand in hand with the revolulutionary peasantry and fight the treacherous bourgeoisie. This sounds very plausible and very revolutionary since the proletariat, together with the peasantry, would probably be able to bring the revolution to a victorious issue, even without the assistance of the bourgeoisie. Unfortunately, not everything which sounds plausible and revolutionary is in reality so, and in our opinion the other section of the Russian Social Democracy, that under Plekhanov, is nearer to the truth." "Is there any sane man at the present moment", the article continued further, "who doubts that the present Revolution in Russia cannot lead to socialism, but must end in the substitution of a bourgeois regime for the present autocracy?"1

The 1907 Congress, attended by some 300 delegates, was riven by the most violent factional war and lasted some three weeks. It was held in the now demolished, socialist Brotherhood Church at Southgate Road, Islington. Amongst those present were Plekhanov, Axelrod, Martov, Lenin, Gorky, Trotsky, Stalin, Zinoviev, Luxemburg, Rykov, Kamenev, Pokrovsky, Smirnov, Tsereteli and others. Stalin had only a deliberative vote and did not speak. ${ }^{2}$

Expenses for the 300 delegates were high. Although Angelica Balabanova had arrived with a handsome donation from German Social Democracy towards the costs of the congress funds began to run short. ${ }^{3}$ Efforts were made to raise $£$, 00 to save the congress from disaster by borrowing from wealthy sympathisers. Theodore Rothstein was persuaded to approach $\mathrm{H}$. N. Brailsford, his colleage on the "Daily News" and ask for assistance. Brailsford suggested they approach Joseph Fels, a well intentioned soap millionaire, a devotee of Henry George's single tax, who had been born in Russia and had subsequently made a fortune in the United States. Rothstein and Brailsford visited Fels at his office in the city. After consulting George Lansbury, Fels agreed to advance a loan. The four collected the cash from the bank and drove by taxi to Islington, arriving at the hall in the midst of one of Lenin's speeches. Fels ever optimistic gave to Lenin one of his single tax pamphlets. In exchange for the money he received a promissory noted signed by the party's leaders. After the Revolution the debt was duly repaid by the Soviet Government. ${ }^{4}$

1 Justice, 30.3.1907: "Social Democrats and their Tactics in the Russian Duma".

2 Angelica Balabanova, My Life as a Rebel, London 1938, pp. 85-9I; L. Trotsky, Stalin, London I947, pp. 89-92.

3 Angelica Balabanova, My Life as a Rebel, p. 86, 89 .

4 Angelica Balabanova, My Life as a Rebel, p. 90; Raymond Postgate, The Life of George Lansbury, London I951, 69-70; L. Trotsky, My Life, p. 202; H. N. Brailsford, Plebs 
Not only were the English Social Democrats responsible for saving the 1907 congress from disaster, the relationship was sufficiently close for Quelch to be invited to bring fraternal greetings to the congress. He promised "Not only in words, but as brothers in deeds, we are willing to help you ... we assure you of our readiness to help you in your great cause". ${ }^{1}$ The SDF lived up to its word. When the delegates were troubled by police surveillance Will Thorne, a member of the $\mathrm{SDF}$, raised the issue in the House of Commons. ${ }^{2}$

On the 24 May at Holborn Hall, the SDF organised a massive welcome demonstration in honour of the delegates. Hyndman took the chair, Quelch and Cunninghame Graham were amongst the speakers. Quelch wittily "welcomed the delegates to our shores or rather our landlords' shores", Balabanova "delivered one of the finest speeches ever made by a woman in England." Amongst the other orators was Leon Trotsky, future organiser of the October Insurrection. It was the only public speech he was ever to make in Great Britain. Ironically his French was translated by A. S. Headingly, who during the world war would become a wild jingo and a violent opponent of the Bolshevik regime.

"Justice" was obviously very much impressed. The "Russian comrades", it reported, "struck one as scholars, mainly young men, slender, with clever, intellectual looking faces. It did not need the physiognomist to tell us that here were the most vital elements of modern Russia." "One felt that here one was in the presence of some of the noblest men and women that the world had ever produced."3

Nevertheless, the differences between "The Majority" and "The Minority" sections of the Russian Social Democratic Labour Party continued to puzzle British Socialists. Thus Elia Levin, a member of the Whitechapel and Stepney Branch of the SDF wrote in explanation: "If the 'Majority' wing (Bolsheviks) is saturated with Blanquist tendencies, the other wing cannot be said to be free from Opportunism ... the watchword 'Do not fight the Liberals when there is a danger of reaction' was turned into 'Do not fight the Liberals even when there is no such danger."'4

Magazine, Tillicoultry, May 1948 , pp. 86-88. Trotsky puts the figure at $£_{3,000}$. The accounts vary over details.

${ }^{1}$ Guy Aldred, No Traitors Gait, Glasgow, p. 281. Quelch spoke an 16.5.1907. The Congress lasted from May 13 th to June Ist.

${ }^{2}$ Hansard 27.5.1907, Col. ${ }_{3} 19$. "I beg to ask the Secretary of State for the Home Department whether he is aware that the Russian delegates who are now holding a conference in London are being shadowed and their photographs taken by private detectives and the police, and whether he intends taking any action in the matter?"

3 Justice, 1.6.1907.

4 Justice, I 5.6.1907. 
The discussions between the two Russian factions were sharp and bitter. One of the Mensheviks asked me, said Lenin, "what was after all the real reason for the discussion?" "This is what it is, I said to him", Lenin replied, "Your friends want to get into Parliament, while we believe the working class has got to prepare for a struggle."1

Before it was over the 1907 Congress, by perpetuating the split between Bolsheviks and Mensheviks which had began four years earlier, had completed the breach between the revolutionary and reformist wings of the Russian socialist movement.

The presence of so many Russian revolutionaries in London did not fail to attract the attention of both British and Czarist secret police. ${ }^{2}$ Not long before the Congress began an anarchist group had established what proved to be a very successful Arbeter Fraint (Workers Friend) Club in Jubilee Street, Stepney. Comprising a hall seating 800, a library, a printing press, a number of rooms for meetings and facilities for refreshments it was one more indication of the size of the immigrant community and of the new burst of life which the I905 Revolution had brought to the exiles in London. Kropotkin and other prominent Russian refugees were regular visitors. ${ }^{3}$

The Club, which later attracted attention in connection with the Sidney Street affair ${ }^{4}$ was kept under constant police surveillance. According to a special branch officer's memoirs, Lenin visited it at the time of the 1907 congress. Inside the hall he recognised a Russian police spy. In the disturbance that followed only intervention by special branch officers saved the spy from a violently hostile crowd. Lenin and four others were arrested. Three prominent refugees, Kropotkin, General Mandorff and Baron Kening testified on his behalf and he was released later the same night. ${ }^{5}$

To a generation which has grown up since the 1917 Revolution it is perhaps a little difficult to convey the widespread detestation in which Czarist despotism was held by manifold classes and opinions in Britain. A "Society of Friends of Russian Freedom" which sought to aid and assist victims of Czarist tyranny had been formed as early as $1890.6 \mathrm{~J}$. F. Green, at one time a member of the SDF executive, was

${ }^{1}$ M. Gorki, Days with Lenin, London 1933, p. 18 .

2 Harold Brust, I Guarded Kings, London I935, pp. 87-88.

3 The Club was opened on February 3 rd, i 906 . R. Rocker, The London Years, p. 178.

4 Harold Brust, I Guarded Kings, London 1935, pp. 90-94; Harold Brust, In Plain Clothes,

London 1937, Pp. 22-25.

5 Harold Brust, I Guarded Kings, p. 89.

B Society of Friends of Russian Freedom, London, Pamphlet Library of London School of

Economics and Political Science. 
prominent in its activities. ${ }^{1}$ Robert Williams, later to be a leader of the Transport Workers Federation and a founder member of the Communist Party, was also active in the organisation. In part at least as the result of the society's activities, thirty-two of the crew of the cruiser "Potemkin" which mutinied during the igos Revolution were able to obtain asylum in Britain. Matutchenko, one of the seamen's leaders, and others of the crew, lived for some time at Stepney, in the very heart of the East London emigré colony. ${ }^{2}$

In such circumstances those exiles who came to take part in British political life, must, one supposes, have brought with them a certain aura of revolutionary authenticity which would have caused their words and actions, within limits, to have carried a rather more than average specific gravity within the councils of the left. Examples of first generation immigrants rising to prominence seem to be rare. ${ }^{3}$ Amongst the second generation they became rather more common. ${ }^{4}$ Thus Theodore Rothstein, son of a Jewish doctor, who emigrated to Britain in 1891 , joined the SDF in 1895 at the age of 24 and by $190 \mathrm{r}$ had been elected to the party executive, a feat, which in view of the almost feudal allegiance which Hyndman was sometimes able to command was an indication of considerable personal merit. ${ }^{5}$

Rothstein, a journalist by profession, wrote several pamphlets, for the SDF, contributed to "Justice" and became something of an authority on the conditions of Egypt under British imperialism. He was throughout this period a man of some importance in the affairs of the party. ${ }^{6}$ He did not fail to raise his voice against what he considered to be the hidebound rigid attitudes of the SDF regime during the early I900's.

The SDF, Rothstein warned, might "degenerate ... into a mere sect." It was in danger of "withdrawing from the world which it despairs of influencing and reforming." "Innumerable ... things which ... frequently leave us indifferent, are of the utmost importance to the proletarian class." "It is generally assumed", he continued, "that educational work ... can be carried on mainly, if not solely ... by bringing our principles before the public and by making the latter understand them. Nothing is farther from the truth ... [it] can gain

\footnotetext{
1 As above.

${ }^{2}$ R. Rocker, The London Years, pp. I $72-174$.

3 Peter Petroff would seem to be an exception. The matter was obviously affected by age, education and general social and cultural background.

4 Zelda Kahan, J. Fineberg and in a sense Theodore Rothstein are examples.

5 See preface to Theodore Rothstein, From Chartism to Labourism, London 1929.

- Rothstein worked for the Manchester Guardian and the (Liberal)Daily News amongst other journals. He was author of Egypt's Ruin, London igro.
} 
but solitary proselytes in the persons of those who live largely by ideas ... the great mass of people cannot be reached by it." "Action is ... the great educator ... [it] drags into its orbit ... all the near standing bodies ... welds them into one common faith and one common enthusiasm."1

Rothstein's criticisms, brusquely dismissed by Harry Quelch, editor of "Justice", 2 went by default and it was not long before one group of dissatisfied members, dubbed by Rothstein "impossibilists" on account of their extreme views, left the party altogether setting up a separate organisation of their own, largely based on Scotland. In later years they were to provide an important contingent of members of the Communist Party of Great Britain. ${ }^{3}$

The nascent political antagonism between the hidebound SDF leadership and the more volatile foreign immigrants was heightened by what can most kindly be termed the racial prejudice shared by certain of the SDF leaders.

Hyndman, whose biographical references to "the increase of the domination of German Jews in finance" and to the "prominence ... of the Israelite" in the City, show an orthodox Victorian upper class hostility to the Jews, did not fail on occasion to introduce his personal feelings into political life. ${ }^{4}$ Thus shortly before the Boer War, he denounced at a meeting in Trafalgar Square, "the scoundrelly adventurers who had got hold of the mining country of the Rand" and 'disdainfully recited the 'good old British names' of Eckstein, Beit, Solomon, Rothschild and Joel". ${ }^{5}$ East London was a centre of Jewish immigration and it was not surprising that at the party conference the following year a delegate from that area should have risen to complain that Hyndman caused "real damage" to the party. As a direct result a resolution was passed, regretting "that any impression should have gained ground that 'Justice' by its articles, or the SDF generally, is in any way antisemitic." 6 The need to pass the resolution was however a sufficient indication of the attitude in a certain echelon of the party.

Neither Hyndman nor "Justice" were however easily muzzled. References of this type continued to rally an important section of the East London Jewish membership against the Hyndman regime.

\footnotetext{
${ }^{1}$ Social Democrat, London, June 1900.

2 Social Democrat, July I900.

3 Thomas Bell, Pioneering Days, London 1941, pp. 38-41, 178 et seq.

4 H. M. Hyndman, Further Reminiscences, London i 912 , p. 199.

${ }^{5}$ F. J. Gould, Hyndman - Prophet of Socialism, London I928, p. I 29.

6 Justice, I I.8. I 900 .
} 
As late as I9 I I, "Justice"1 would call a Liberal candidate "a billionaire Austrian Jew", "impertinent and arrogant", "owing his position ... to the weight of money bags behind him." Joe Fineberg, a Polish born tailoring worker, secretary of the Stepney and Whitechapel Branch, protested ${ }^{2}$ but obtained no satisfaction. In defence the editor of "Justice" pleaded "no offence ... intended" and then made matters worse by a further reference to "wealthy Jewish princes" in his reply.

In the years that preceded Hyndman's dethronement in April 1916, sections of the East London membership would prove to be amongst his most relentless opponents. That this was largely political there can be no doubt. That it was heightened and bound together by a common resentment of Hyndman's prejudice against those "Jews" and "foreigners" who constituted such a large part of the party's membership and supporters in this area would seem equally certain.

Hyndman, a much abused man, has been harshly blamed for his actions by critics whose political consistency in some cases compares most unfavourably with his own. ${ }^{3}$ The advocacy of a "Big Navy" policy which sounded so strange to socialist ears in the decade before I9I4 was based on a fear of naval blockade of Britain which had first appeared in Hyndman's "England for All" published as long ago as $1881 .{ }^{4}$ Previously an unfortunate eccentricity, Hyndman's nationalist views became an ever more serious handicap to the SDF in the years of growing international armament competition which preceded I9I4. Thus at the conference of I906 Hyndman's dissertation on "War and Socialism" provoked a complaint from B. Kahan, a delegate from one of the East London branches. ${ }^{5}$ Kahan was a Russian emigré, his daughter was later to become one of the leaders of the struggle against Hyndman within the SDF.

When in July I 9 ro Hyndman wrote to the staunchly Conservative "Morning Post" 6 demanding a £ 100,000,000 increase in the Navy Estimates, expressing the opinion that "German Social Democracy could not hope to check a war - if the Emperor ... had decided on it. A powerful navy is ... a defensive necessity." a large part of the ensuing flood of protest came from the East London membership. The Central Hackney branch, a centre of the opposition, demanded

1 Justice, 5.8.191 I; J. P. Eddy, The Mystery of Peter the Painter, London I 946.

2 Justice, I2.8.1911.

3 Thus Morton and Tate, The British Labour Movement, Lawrence \& Wishart, London I956, p. I65, describe Hyndman as "at bottom a bourgeois political boss", although by comparison with the British Communist Party the SDF was a veritable paragon of honesty, socialist principles and internal democracy.

${ }^{4}$ H. M. Hyndman, England for All, London I88I, pp. 169-1 7x.

5 SDF Conference Report, London 1906.

6 Morning Post, London 6.7.1910. 
that Hyndman "desist from these utterances"1 and in what began to look like a concerted move, branches at Enfield, Whitechapel, Bethnal Green, St. Georges, Finsbury and Camberwell, made similar demands. Zelda Kahan, B. Kahan's daughter went so far as to warn that "if the SDP1 does not speedily ... repudiate such bourgeois imperialist views then goodby to it as a serious force in the national and international Socialist movement."2

Hyndman's advocacy of increased naval expenditure served to initiate the formation of an "Internationalist" opposition to his views on defence, an opposition in which both British and foreign emigré critics were combined. Thus at the Conference in Easter the following year, Zelda Kahan moved a resolution demanding that "Executive organ and individual members ... combat with their utmost energy, the demands for increased armaments and to demand ... the abandonment of all colonial and financial aggression, and the cessation of any provocative or obstructive policy in its relations with the powers."

The resolution was a forthright challenge to the Hyndman regime which found itself hard pressed and in danger of losing the vote. By a prearranged manœuvre, the closure was moved in the middle of the debate. Although Hyndman and Quelch had together spoken for so minutes, neither Kahan nor any member of the opposition was given the right to reply. The vote tied 28 to 28 . Hyndman was saved only by a branch vote (not necessarily more representative) which registered $47 / 33$ in his favour. ${ }^{3}$

Lenin commented on the dispute in an article written barely a fortnight later, a fact which would seem to point to a close link with some at least of the members of the SDP.4 Deploring Quelch's "miserable sophistry" Lenin described the Hyndmanite victory as deplorable, expressing the view that "Zelda Kahan was right" and his opinion, which was to prove well founded, that "a very strong minority was found for serious struggle."

The conference was barely over when the arrival of the German cruiser Panther at Agadir seemed about to plunge Britain and France into a new European war. "Justice" came out in defence of British interests. W. P. Coates, later to marry Zelda Kahan, and to become

\footnotetext{
1 Justice, 30.7.1910. B. Kahan's daughter, Zelda Kahan, was a member.

2 Justice, 20.8.1910. Grown from the Democratic Federation founded in $188 \mathrm{I}$, the Social Democratic Federation founded in 1884 , became the Social Democratic Party in 1908, merged into the British Socialist Party in 1912 and finally dissolved itself as the largest single contingent into the Communist Party of Great Britain in 1920.

3 Justice, 22.4.1911.

4 Lenin on Britain, PP. I I3-II5. Article dated 29.4.19II.
} 
with her one of the British Communist Party's Russian experts, wrote angrily: "We are opposed to imperialism of any kind ... then why should Germany more than any other capitalist country be everlastingly singled out for attack?"1 Theodore Rothstein put the issue more bluntly: the "ethical considerations, with which you have been regaling us are so much bunkum ... what you cannot tolerate is the idea that anyone should presume to hunt in British preserves."

The Agadir crisis eventually passed without further incident. Hyndman's forthright advocacy of a "Big Navy" policy, his continual warnings about the need to prepare against the contingency of war with Germany ensured the perpetuation and growth of the "Internationalist" opposition.

Continental Social Democracy had adopted the slogan of the "Citizen Army", a people in arms, as a socialist alternative to the conscript armies of the great European Powers. Hyndman and his allies had adapted this policy to Britain, in which, alone of the Great Powers, conscription did not exist. As a result the largest section of the Labour Movement and a considerable minority in the Party's own ranks were inclined to accuse them of advocating conscription in disguise.

At the conference in I9I 2 the official policy was subjected to a serious challenge from the floor and only obtained endorsement by 18 votes in a conference of over 200 delegates. $^{2}$ In the leadership elections Zelda Kahan secured a place on the Executive - a resounding victory for a woman at that time still in her twenties. ${ }^{3}$

That December a resolution, moved at an Executive meeting by Kahan, was carried by a narrow majority, stating the party ".. disassociates itself from the propaganda for increased naval expenditure..." calling "upon the British Government to desist from its provocative attitude towards Germany ... and to decrease its expenditure upon armaments." Since the executive had previously carried a motion, that "it was not open to members of the executive to attack the expressed opinions of the majority", the Hyndman group seemed to be effectively gagged.

The ensuing crisis threatened to split the party. In February the divided executive suspended its previous resolution and referred the whole matter to the forthcoming party conference. ${ }^{4}$

\footnotetext{
1 Justice, 15.7.1911. William Peyton Coates, USSR and Disarmament, Anglo Russian Parliamentary Committee, London 1928 etc. William Peyton and Zelda Coates, Armed Intervention in Russia 1918-1922, London 1935.

2 British Socialist Party Conference Report, London 191 2, pp. 20-22. The vote was 83 to 65.

3 British Socialist Party Conference Report, London rgr 2, p. 3 .

4 H. W. Lee and E. Archbold, Social Democracy in Britain, London 1936, pp. 21 2-213.

British Socialist Party Conference Report, London 1913, Pp. 36-38.
} 
When the conference met in April the situation was very tense. The Hyndman attitude to the Navy programme came under heavy fire. Peter Petroff, a participant in the Revolution of 1905 , and later to play an important role in the war time upsurge on the Clyde opposed the Hyndmanites on behalf of Kentish Town. Zelda Kahan pointed out that "Hyndman's ... views on armament made people ... think that he was [a jingo] and [that he] was putting the BSP entirely outside the International". 1

Confronted with widespread opposition, Hyndman, whilst holding fast to his views, offered as a compromise, "not to enter on a discussion of the question or to raise it in any way that would prejudicially affect the party." Amidst a burst of applause, the offer was accepted. Hyndman and Kahan shook hands. A fresh resolution expressing support for the resolutions carried by the Socialist International at Stuttgart in 1907, and Basle in 1912, was carried by a large majority. ${ }^{2}$ Lenin, writing from a distance, expressed approval of the rise of new figures to the executive in the election that followed. ${ }^{3}$ The conflict over the arms budget now died down, only to re-emerge in sharper form with the outbreak of hostilities in rir 4.

Amongst the London members who were now beginning to emerge as an alternative leadership to the Hyndman "Old Guard" one of the more formidable was Peter Petroff. A twice wounded combatant in the Revolution of I 905 , Petroff had reached Glasgow after escaping from exile in Siberia in 1907. John Maclean, later to become the most famous of Clydeside militants had sheltered Petroff and taught him English. When a Russian cruiser called on the Clyde for repairs, Petroff as an organiser for the RSDLP made contact with the crew and according to one contemporary used to take them for rambles through the Kilpatrick Hills and lecture them on socialism for hours on end. Petroff according to the same source was on personal terms with both Lenin and Trotsky.4

At the Conference of I914 Maclean and Petroff in an endeavour to strengthen the opposition, both backed an unsuccessful proposal to bring "Justice", hitherto in the hands of the Hyndman group, under direct party control. ${ }^{5}$

One year before Petroff had carried two important resolutions. The first called on the party to take an attitude on the political issues of the day and by implication to abandon its existing emphasis on a

\footnotetext{
${ }^{1}$ British Socialist Party Conference Report 1913, p. 17.

2 British Socialist Party Conference Report I913, p. 18.

${ }^{3}$ Lenin on Britain, pp. I I 5-I I 7.

4 Testimony of James MacDougall, Glasgow, a prominent participant in these events.

5 British Socialist Party Conference Report, London I9r4, p. 9.
} 
rather sterile doctrinaire propaganda. The second called on the BSP "to lead the working class in its economic and political struggle" and "to organise the trade union members of the BSP for systematic work and socialist propaganda in the trade unions."' Both resolutions in some degree anticipated the attitude to working class politics which the success of Russian Bolshevism would implant after 1919. They constitute an interesting index of the extent to which a measure of Russian radicalism was already entering British marxist politics.

The question of the extent to which these tendencies might have gained support and influence by their own intrinsic merits is indeed of great importance. The issue however was not to be put to the test. The outbreak of war in August 1914 brought all the existing conflicts within the SDF to a head. The party's development was wrenched into an entirely different course.

The outbreak of war, the seemingly total collapse of German Social Democracy, hitherto the strongest bastion of the Socialist International, took the SDF by surprise and for a while left the membership hesitant and incapable of effective action. Once the initial shock was over, the Hyndman tendency began to reassert itself once more.

In September I9I4 the BSP executive, in an involved resolution announced its desire "to see the prosecution of the war to a speedy and successful conclusion" and called on the party's representatives, when invited, "to accept" invitations to take part in the general recruiting campaign. ${ }^{2}$ The Executive thus explicitly declared itself for the British Government in its pursuit of the wat against Germany. The BSP left wing was outraged. The executive decision was denounced as a betrayal of the internationalism on which the socialist movement was based, as a contradiction of the Stuttgart Resolution of 1907 and the Basle Resolution of 1912, which the party itself had previously endorsed. ${ }^{3}$ Since both factions in Russian Social Democracy were subsequently to declare themselves against the war the reaction was especially strong amongst the immigrant members of the party.

Branches at Stepney, North West Ham, Bow and Bromley and Central Hackney, all in East London, were amongst the first to express their opposition. Later is of 18 branches assembled at an all London conference would demand that the statement on recruiting be withdrawn. ${ }^{4}$ In October a vacancy arose in the London section of the executive. "At the request of a number of branches and members" Joseph Fineberg, a member of the pre-war "Internationalist" opposi-

${ }^{1}$ British Socialist Party Conference Report I913, p. I9.

${ }^{2}$ Lee and Archbold, Social Democracy in Britain, pp. $225-226$.

${ }^{3}$ British Socialist Party Conference Report 1913, p. 18.

4 Justice, 24.9.1914, 1.10.1914, 22.10.1914. 
sition, stood "as an opponent of the [recruiting] manifesto" and the "action of the government in declaring war." Fineberg polled 25 votes, six other candidates only 29 between them. Peter Petroff, Maclean's ally markedly to the left of Fineberg, polled as heavily as Victor Fisher, the party's most chauvinistic propagandist. ${ }^{2}$

The Hyndman group, resisting pressure from below, now decided, that in view of wartime difficulties it would be impossible to hold a national conference in I9I9. Instead plans were announced for six regional gatherings, the votes to be aggregated for the purpose of reaching decisions. ${ }^{3}$ The measure was seemingly intended to atomise a growing opposition. The critical tone of the conferences was set by the East London branches, but the outcome, perhaps due to vote rigging, proved inconclusive. ${ }^{4}$

The party was now faced with a recrudescence of the patched up conflict which had been ended only shortly before the war. The intensity of the factional division was increased by the growing immensity of the international conflict. The issue at stake was the power of the party machine and resources. The faction which emerged as final victor in that struggle was unlikely to be able to bear the continued presence of the other within the party's ranks. Conflicts in Britain were sufficient to cause problems, the influence of outside factors was to render their solution insuperable.

On I4 February, I9I s, an "Allied Socialist Conference" was held in London. ${ }^{5}$ The BSP executive by a majority decided on participation. Keir Hardie occupied the Chair. Maxim Litvinov, Bolshevik representative in London, insisted on presenting a forceful document calling for a united struggle of both "Allied" and "Enemy" socialists against the continuation of hostilities. After two interruptions from Hardie the Bolshevik representative walked out in protest. ${ }^{6}$ Not long afterwards the BSP's Kentish Town branch (of which Chicherin later Soviet foreign minister was a member) protested that the Conference was an attempt "to destroy the International" and deplored the BSP's participation.?

1 Justice, 8.10.1914.

2 Justice, 5.1r.1914.

3 Justice, 3.12.1914.

4 Irma Petroff in a letter to the author. The votes cast were collated and totalled at the National Office in London. Lee and Archbold, Social Democracy in Britain, pp. 223-235; Justice 4.3.1915.

${ }^{5}$ Lee and Archbold, Social Democracy in Britain, pp. $232-233$.

6 A. U. Pope, Maxim Litvinov, pp. I03-ז Iо. Litvinov's report of the proceedings was first published in Trotsky's Nashe Slovo on 27.12.1915. A fuller version, unmutilated by French censorship, appeared in the Zurich Sozialdemokrat 29.3.1915.

7 Justice, I 5.4.1915. 
The truth was that the organisation of the International had become a hostage of the Allies. ${ }^{1}$ In consequence the more irreconcilable opponents of the war were driven into opposition to the International itself and towards an attempt to establish a fresh organisation of international socialist anti-war co-operation. During ig Is the Italian deputy, Ordino Morgari, had been touring Europe endeavouring to re-establish international contacts. ${ }^{2}$ As a consequence the BSP executive now received a request to be represented at a forthcoming conference of anti-war socialists to be held at Zimmerwald in Switzerland. After some hesitation the executive decided to send E. C. Fairchild of Central Hackney, ${ }^{3}$ one of its number as an observer. In the event, neither Fairchild nor Bruce Glazier, the observer similarly appointed by the ILP, received governmental authority to travel and in consequence never departed. ${ }^{4}$ The Zimmerwald resolution was eventually published in "Justice"5 The Hyndman wing firmly committed to the victorious prosecution of the war found it entirely unacceptable. The group around Fairchild committed to the rebirth of the Second International, firmly opposed to the creation of a fresh organisation, found itself sympathetic to the views expressed, yet hostile to key practical proposals. ${ }^{6}$

Throughout I9Is, "Justice" under the editorship of H. W. Lee? continued to aggressively support a pro-war policy. A bitter conflict developed, centred around the fact that the paper was controlled by the Hyndman group, independent of the executive, by virtue of their dominance of the printing and publishing company, the Twentieth Century Press. In July, Zelda Kahan, found it necessary to warn that unless the editor abandoned his pro-war stand the opposition would have "nothing to do with the paper and even ...

1 When the Italian Deputy Ordino Morgari visited Vandervelde, Chairman of the International Socialist Bureau, he was notified "As long as German soldiers are billeted in the homes of Belgian workers there can be no talk of convening the Executive." "Is the International then a hostage in the hands of the Entente?" asked Morgari pointedly.

"Yes, a hostage", came the blunt reply. Deutscher, The Prophet Armed, p. 225.

2 British Socialist Party Conference Report 1913, pp. 39-40.

3 Central Hackney in East London was one of the more militant BSP branches. BSP Conference Report 1913, p. 40.

${ }^{4}$ Lee and Archbold, Social Democracy in Britain, p. 235; British Socialist Party Confer-

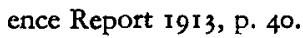

5 Justice, 30.9.1919.

- British Socialist Party Conference Report I916, pp. I3-14; British Socialist Party Conference Report I9I7, p. I I.

${ }^{7}$ Quelch had resigned his post as editor in 1913 and been replaced by Lee. Lee and Archbold, Social Democracy in Britain, p. $21 \mathrm{I}$. 
hinder its circulation". ${ }^{1}$ In September John Maclean in Scotland, unwilling to leave the issue in the balance any longer, launched through the medium of the Glasgow Divisional Council his own rival anti-war socialist monthly, "The Vanguard"."2

"The Vanguard" proved the most radical of the wartime socialist journals. Peter Petroff became a regular contributor. The paper welcomed the Zimmerwald Manifesto, adopting a line closer to Lenin and the Bolsheviks than that of any other section of the Labour Movement. ${ }^{3}$

Petroff's wife was a German socialist, resident in Britain. Petroff's articles were published in Trotsky's "Nashe Slovo" in Paris. One of his closest colleagues states that Petroff's material was translated into German by Robert Grimm in Switzerland and by this route reached and influenced Liebknecht and other social democrats in Germany. ${ }^{4}$ At any rate, Maclean himself felt strongly enough to declare, "the revolt of some German Social Democrats against voting for a new war loan was probably stimulated by the strike on the Clyde" and he may well have had substantial ground for this belief. ${ }^{5}$

At the time of the first publication of "Vanguard" in the autumn of I9I5, Maclean had been expecting arrest by the authorities. In consequence he called Petroff up from London to assist with the paper and to replace him if necessary.

On the 23 December an article in "Justice" openly incited the authorities to Petroff's arrest. ${ }^{6}$ Shortly after Petroff was taken into custody, charged, sentenced and held in a Scottish prison until his release and repatriation to Russia after the Revolution of 1917 . Chicherin and Litvinov were amongst those who rose to his defence. ${ }^{7}$ Their efforts proved of no avail.

The arrest and imprisonment of Peter Petroff was an indication of the level of government concern at the Scottish situation. Clydebank was a major centre of shipbuilding and munitions production. The emergence of a radical shop stewards movement which had led an important unofficial strike earlier that year led the authorities to fear that the pending introduction of full scale military and industrial conscription would produce a wave of protest strikes and popular

\footnotetext{
1 Justice, 8.7.I915.

2 Tom Bell, John Maclean, Glasgow 1944, p. 39.

${ }^{3}$ Vanguard, December 19I5.

4 Testimony of James MacDougall, Glasgow in conversation with the author.

5 Forward, Glasgow 8.5.1915.

Who and What is Peter Petroff, Justice 23.I2.1915.

7 British Socialist Party Conference Report 19I6, pp. 20-2I. Trotsky's Nashe Slovo also protested; see Vanguard, December 1915. The Call, 30.3.1916.
} 
resistance. ${ }^{1}$ Maclean and Petroff in "The Vanguard" were exerting every effort to this end. Feeling was so strong that according to one account, some Lettish veterans of 1905 had raised the question of armed insurrection on the Glasgow District Council of the BSP. ${ }^{2}$ The Clyde Shop Stewards were now publishing a short lived journal titled "The Worker". In a counterblast against revolutionary aspirations the journal published an article titled "Should the Workers Arm?" attacking openly those whose "minds turn pleasurably in the direction of rifles, bombs and dynamite". ${ }^{3}$ The article provided the pretext for a prosecution. By April 1916 the entire Clyde shop steward leadership was either in enforced exile or in jail. ${ }^{4}$

Petroff had been arrested soon after the publication of the "Justice" article of December I9I5. Maclean, arrested in February, ${ }^{5}$ followed him to jail in April 1916.6 "The Vanguard", hitherto the sole challenge to the BSP's "official" "Justice," was now closed down.?

State action against anti-war elements within the socialist movement was bound to hasten the development of a crisis between the patriotic leadership and the anti-war opposition within the BSP. Petroff and Maclean were both members of the party, as were some of the jailed and exiled shop stewards leaders. ${ }^{8}$ As early as May i91 5 , E. C. Fairchild and Joe Fineberg, the two London members of the Party executive, had decided to call a special London conference to discuss the party's attitude to the war, a measure obviously intended to rally the opposition against the Hyndman regime. 9 The enforced closure of "The Vanguard" left the growing opposition without an organ with which to challenge "Justice" of the official regime. The most radical wing of the BSP was that led by John Maclean and supported by Petroff and MacDougall. Once these were jailed, the leadership passed to the inheritors of the pre-war "Internationalist" opposition, amongst whom E. C. Fairchild of Central Hackney was the most prominent figure, and Fairchild and Fineberg the two longest standing executive representatives. In February I916 this tendency now launched their

1 Lloyd George, then Minister of Munitions, visited Clydeside in December I9 I s, with a view to winning support for government policies amongst the industrial workers. William Gallacher, Revolt on the Clyde, London 1949, p. 31 et seq., p. 78 et seq.

${ }^{2}$ Edward Doran, former Glasgow member of the British Socialist Party, in conversation with the author.

3 The Worker, Glasgow, 29.1.rgr6.

4W. Gallacher, Revolt on the Clyde, p. I Is et seq. T. Bell, John Maclean, pp. 57-59.

5 The shop stewards leaders were arrested on 31.I.19I6, John Maclean one day later.

6. Bell, John Maclean, pp. 57-62.

7 In January 1916. T. Bell, John Maclean, p. 40.

${ }^{8}$ Gallacher for example. Revolt on the Clyde, Pp. 6, $205-207$.

Oustice, 27.5.1915, 3.6.1915. 
own journal "The Call" presumably as part of preparations for the forthcoming annual conference of the BSP. Fairchild was appointed editor, Rothstein, under the pen name "John Bryan" became a frequent contributor. ${ }^{1}$

The BSP conference at Salford in April 1916 met in the aftermath of the Clyde arrests and the general imposition of military and industrial conscription. In heated exchanges some of the Hyndmanites were charged with direct personal responsibility for police action against members of the anti-war opposition. ${ }^{2}$ The outcome was a scene in which the Hyndmanites walked out in a body leaving the Internationalists in control of the party machine. "Justice", however, remained in the hands of the Hyndman Group. In the hard fought battle for control which followed the new leadership were narrowly defeated. "Justice" now passed out of the party's influence altogether. "The Call" became the official party organ. ${ }^{3}$

The defeat of the Hyndman group, the rise to office of the former opposition were obviously factors of major importance in ensuring that in the following year the BSP would endorse the successive Russian Revolutions of March and October 1917. Yet this should not hide from us the fact that surprisingly close connections existed between the BSP and Russian revolutionaries even in the year 1916. Trotsky's "Nashe Slovo", published in Paris, was already eclipsing Lenin's Viennese "Pravda" in both style and influence. ${ }^{4}$ Peter Petroff and Theodore Rothstein were both contributors as was Chicherin, at this time, a member of Kentish Town branch of the BSP and later Foreign Secretary of the new born Soviet Republic, facts which would seem to suggest that its influence amongst London emigrés was also considerable. ${ }^{5}$ Amongst the Parisian supporters of the paper were Antonov Ovseenko, Lunacharsky, Ryazanov, Lozovsky, Manuilsky and Sokolnikov, all later to play an important role in the post revolutionary Communist leadership in Russia. ${ }^{6}$ When in September 1916 the French authorities suppressed "Nashe Slovo" and expelled Trotsky from France, "The Call" in its next issue? protested. When Trotsky's

1 The first issue of The Call appeared on 24.2.1916.

2 British Socialist Party Conference Report 1916, p. 3 ; Lee and Archbold, Social Democracy in Britain, pp. 236-237.

${ }^{3}$ Lee and Archbold, Social Democracy in Britain, p. 239; British Socialist Party Conference Report r9i 7, p. 23-24.

4 Isaac Deutscher, The Prophet Armed, p. 22 I.

5 Isaac Deutscher, The Prophet Armed, pp. 222-223. Author's conversation with James Macdougall.

${ }^{6}$ Isaac Deutscher, The Prophet Armed, pp. $221-222$.

7 Isaac Deutscher, The Prophet Armed, p. 238; The Call, 21.9.1916. Nashe Slovo was banned on 15.9 .1916 . 
position in Spain grew dangerous "The Call" did not fail to raise a prompt voice in his defence. ${ }^{1}$

In such circumstances it was not surprising that the March 1917 Russian Revolution, which with the overthrow of Czarism brought warm support from the largest section of the British labour movement should have been especially welcomed by the BSP. That year Lozovsky, one of the adherents of the suppressed "Nashe Slovo", later chief of the Communist, Red International of Labour Unions, contributed an article to the May Day issue of "The Call"."

The following month, J. Baum, a delegate from the Petrograd Soviet, arrived in England. ${ }^{3}$ Lozovsky and other Russians in Paris exile now visited Britain to join the BSP in discussion with the Soviet Representative. ${ }^{4}$ During his stay Baum attended a specially convened joint meeting of BSP and ILP leaders. In July four Russians, Ehrlich, Goldenberg, Smirnov and Posonov arrived in London charged with the duty of re-establishing contacts with the British socialist movement. Two of the four BSP members of the reception committee, Chicherin and $B$. Kahan, were products of the immigration. The others were Inkpin, the party secretary, and Tom Quelch, son of the former editor of "Justice" and now a leading figure in the party. ${ }^{5}$ The BSP made arrangements for the Russian delegation to address a public meeting at the Brotherhood Church at Islington in which the historic Menshevik/Bolshevik split had taken place in 1903 . In the event the meeting was invaded by a mob of rowdies and ended in disorder. The eruption it seems had been inspired by Sir Basil Thomson, Chief of the Special Branch at Scotland Yard. ${ }^{6}$

There can be little doubt that the arrival of delegates from Russia did a great deal, especially amongst the upper echelons of the party, to clarify the widespread confusion about the political situation existing at that time. The BSP following the defeat of Hyndman in I9I 6 had come out against the war yet without specifying in what conditions, if any, national defence might be justified. One section of the membership was in favour of a negotiated peace. Another looked to mass action and revolution for an end to the war. The boundaries between each tendency were not clearly drawn, the attitudes of pacifism and political opposition improperly distinguished.

x The Call, 23.11.1916.

2 The Call, 26.4.1917. On May Day 1918 The Scottish Socialist Labour Party was selling in Glasgow a secretly printed edition of 'Trotsky's War and Revolution.

3 The Call, 21.6.1917.

4 The Call, 21.6 .1917$.

5 'The Call, 26.7.1917.

${ }^{6}$ Sir Basil Thomson, The Scene Changes, New York 1937, p. 383 et seq. Thomson was appointed in June 1913 ; ibid., p. 242. 
To each section, although to some extent for different reasons, the Russian Revolution was equally welcome.

The development of the Russian situation between March and October I9I 7 would tend to make these differences more precise. The later development of the October Revolution would render them ever more sharp and pointed. Yet since one might legitimately defend Revolution in Russia whilst supporting Reform in Britain it would not be until the rise of the Communist International and with it the implicit obligation for the British party to impose the Russian model on British society that the differences would become irreconcilable.

In the meantime the links between British socialists and the Russian Revolution would continue to grow and to multiply. John Maclean, a lonely man in a Scottish prison suddenly became a revolutionary symbol of international significance. The First All Russian Congress of Workmen and Soldiers Deputies meeting in June cabled "Greetings to the brave fighter for the international proletariat, Comrade Maclean, and express their hopes that a new rise of international solidarity will bring him liberty."2

Later that month, and perhaps in part at least as a result of the Russian action, Maclean was released with his three year sentence only half served.

Maclean's attitude was closest to that of the Bolshevik wing of the Russian Revolution. Within the BSP there now took place a certain debate about the correct course for Russian socialism. The views expressed were by no means as clear-cut and consistent as some subsequent historians seen to maintain. Thus as late as August 1917, Theodore Rothstein, later to become a most important link between British revolutionary socialists and the Russian Revolution, could write that the entry of delegates from the Petrograd Soviet "into the Government, in spite of the violent opposition of the Leninites ... was a great step which marked the official triumph of the revolutionary proletariat."3 The Bolsheviks would not forget the extent to which John Maclean had independently almost alone shared their attitude to the war. ${ }^{4}$ Yet if the Bolshevik/Menshevik issues never at the time appeared in the BSP Press, with the clarity which they were later to

\footnotetext{
1 British Socialist Party Conference Reports 1916, I917, 1918.

2 John Maclean's personal papers in possession of his daughter, Nan Milton.

${ }^{3}$ Plebs Magazine, Oxford, August I917; John Bryan, The Struggle of Classes in Russia, p. 147.

4 The Manifesto of 24.r.1919, from which the establishment of the Communist International dates, invited "The left elements in the British Socialist Party, in particular the groups represented by Maclean."
} 
seem to assume, the fact remains that confronted with the actuality of the October Revolution the BSP gave it unstinting and near unanimous support.

"We have the dictatorship of the proletariat established under our eyes", wrote "The Call" editorial joyfully on November 29. "How long will it last?" Then with an astonishing insight it concluded, "the ... utter exhaustion of the nation ... may ... help to make the Bolshevik rule more permanent than seems at present reasonable."

At the Labour Party Conference at Nottingham in January, I9 18, Maxim Litvinov, now beginning to play an important role in British socialist life, conveyed fraternal greetings from the Russian Revolution to the British Labour Movement. ${ }^{1}$ After meeting Maclean at Nottingham, Litvinov appointed him Soviet Consul for Scotland, a post which Maclean continued to hold until once again arrested and charged, this time with sedition, in mid-April I9 $18 .^{2}$

Litvinov's influence now began to be almost obviously felt in the columns of "The Call" in which he was increasingly featured as a Bolshevik spokesman. Thus in January 1918, "The Call" coupled its own manifesto to the Labour Party Conference with a direct appeal from Litvinov. The party premises were raided and the copies confiscated before distribution could be arranged. ${ }^{3}$

On the weekend of 26/27 January, 1918, the executive formally endorsed the Russian Revolution. A few days later under the head "Bolsheviks Message to the BSP", "The Call" published a whole page appeal for revolutionary action from the Central Executive Committee of the Council of Workmen's, Soldiers' and Peasants' Deputies. ${ }^{4}$

"The Call" and the BSP now began to assume the role of semiofficial spokesman for the Russian revolution within the ranks of the British working class.

Links between the BSP and the Russian Revolution grew steadily stronger. Fineberg, a member of the executive, became Litvinov's secretary. ${ }^{5}$ A number of exiles, encouraged by the upsurge in Russia decided to return home, thus increasing direct ties at both personal and political levels. The first Bolshevik courier to arrive in Britain was

\footnotetext{
1 A. U. Pope, Maxim Litvinov, p. Izo.

2 Tom Bell, John Maclean, p. 69 et seq.

3 The Call, 24.I.191 8. Litvinov's appeal "To the Workers of Great Britain" appeared in the issue of 10.1.1918. The British Socialist Party Manifesto on 17.1.1918. The combined leaflet apparently never left the printshop.

4 The Call, 7.2.1918.

5 The Call, 7.2.1918; Thomson, Queer People, p. 283.
} 
a Russian named Holtzmann who had been for several years an active member of the Central Hackney branch and who had returned to Russia only in the summer of $1917 .{ }^{1}$ Petroff and Chicherin were deported to Russia in January I9 $8 .^{2}$ Trotsky to whose paper Petroff and Chicherin, like Rothstein, had contributed, was now Soviet Commissar of Foreign Affairs and ranked with Lenin as one of the greatest figures of the Revolution.

Petroff became President of the Foreign Relations Committee of the Soviet. After the Brest Litovsk negotiations were broken off and the German Army advanced with disastrous effect for the Soviets, "it was Petroff who was sent out ahead of the Russian lines in a small car to meet the German troops and announce the Soviet decision to accept the German terms."3

After Trotsky's resignation in February 1919, Chicherin was promoted to fill his place as Commissar for Foreign Affairs, a post which he continued to fill for more than a decade.

In mid-1918, Joe Fineberg, for some two years a member of the BSP executive, decided after some hesitation to return to Russia and to give his aid to those who were at that moment desperately struggling to ensure the Revolution's survival. ${ }^{4}$ The Bolshevik leaders now had at their disposal someone exceptionally well informed about the internal affairs of the BSP. Perhaps as a result of arrangements made following Fineberg's arrival, Bolshevik propaganda, including the texts of pamphlets by Lenin and others, began to arrive regularly in Britain and was published through "The Call" and the party press.

Bolshevik influence was further heightened by the fact that Litvinov, as a result of confidential negotiations, had now been granted semiofficial status in exchange for provision of similar facilities for Robert Bruce Lockhart in Moscow. In these negotiations Rothstein had initially acted as intermediary. ${ }^{\mathbf{5}}$

Litvinov, linked by a regular courier line with Moscow, continued to play a certain role in British Labour affairs, being at one time accused of provoking a mutiny aboard a Russian warship in Liverpool. ${ }^{6}$ Rothstein became fairly explicitly the Bolshevik representative

1 The Call, Io.I.1918.

2 Trotsky had threatened reprisals if they were not released, David Lloyd George, War Memoirs, p. 2566; A. U. Pope, Maxim Litvinov, p. 130; The Call, ro. I. 1918.

3 British Socialist Party Conference I9I8, p. 23. Macdougall in conversation with the author.

4 The Call, 13.6.1918, 27.6.1918.

5 Robert Bruce Lockhart, Memoirs of a British Agent, London I932, pp. $201-204$. A. U. Pope, Maxim Litvinov, p. I 30.

6 Sir Basil Thomson, Queer People, London 1922, pp. 287-288; David Lloyd George, War Memoirs, p. 2567 ; J. T. Murphy, New Horizons, London 1941, p. 69. Mac Manus and 
within the BSP and if Sir Basil Thomson is to be believed, a channel through which finance for pro-Bolshevik activities was fed into the ranks of the British socialist movement. ${ }^{1}$

Whilst ties between BSP and Bolshevism were growing closer, relations between orthodox social democracy and the leaders of the Russian Revolution were becoming steadily more estranged. Kerensky, not Litvinov spoke to the Labour Party Conference in June 1918. All attempts to gain Litvinov a hearing were a failure.

Alongside this development differences between the revolutionary wing of the BSP which wished to follow the Russian example and more cautious elements who believed that there was no revolutionary road open to Britain in the conceivable future, grew steadily sharper.

In late 1918 and early 1919 the first steps were taken to re-establish contacts between the parties of the old Second International. In January 1919, the Bolshevik Radio launched a world wide call for the establishment of a new, rival, revolutionary, Third Communist International. There ensued a bitter struggle within the BSP. A small minority led by E. C. Fairchild, editor of "The Call" and H. Alexander, the party treasurer, continued to support their war time demand for the re-establishment of the Second International and steadfastly opposed all proposals to affiliate the BSP to the newly formed Communist International. The majority were in favour of affiliation. Appropriately the first shots in the battle were fired by Rothstein in the columns of "The Call". ${ }^{2}$ Finally, Alexander and Fairchild, amidst considerable bitterness and recrimination resigned and left the party altogether. ${ }^{3}$ A little less than twelve months later the BSP fused its identity into the newly formed Communist Party of Great Britain, to whose ranks its members provided by far the largest contingent.

To estimate accurately the precise influence of the Russian Emigration on the British socialist movement before 19 I 9 would be a most hazardous task. Some conclusions may however fairly be made. It is beyond question that the emigrés by providing leaders of the capacity of Kahan, Rothstein and Fineberg, as well as a body of party opinion to back them, played an important part in the downfall of the Hyndman regime. Nor can it be contested that the national links which the

Bell, two important shop steward leaders, had travelled specially to London to meet Litvinov in February 1917. T. Bell, Pioneering Days, pp. 169, I5 I.

${ }^{1}$ Sir Basil Thomson, Queer People, p. 290.

2 The Call, 17.4.1919. The same issue contained the first report of the Founding Congress of the Communist International which had begun in Moscow on 2nd March, 1919.

3 The Call, 30.10.I919. 
emigrés possessed with other centres, especially France, and later Revolutionary Russia itself, were an important factor in developing international consciousness within the BSP and finally assuring its firm allegiance to the conquests of the October Revolution.

Finally, although this largely lays beyond the purview of our investigation the Russian emigré membership would certainly exert a certain influence on pushing the BSP towards fusion into the Communist Party. Even today East London continues to provide a disproportionately large contingent of British Communists and it seems probable that this phenomenon is not without a direct link with the events which it has been the purpose of this study to describe. 